教育セミナー

\title{
大腸ポリープ・癌の $\mathrm{X}$ 線投影像
}

\author{
佐 藤 正之 \\ 市立吹田市民病院放射線科
}

\section{RADIOGEOMETRIC PROJECTION OF COLON POLYP AND CANCER}

\section{TADAYUKI SATO}

\author{
Dept. of radiology, Suita municipal hospital
}

\section{はじめに}

わが国における死因第 1 位の悪性新生物中依然として 胃癌が最も高率にみられるが，近年その数は漸減傾向を 示している．代って肺癌, 肝癌と共に大腸癌が増加し, 西暦2000年には胃癌を抜いて消化器癌の中で第 1 位の死 因になると予測されている，その対策として大腸検診シ ステムの確立が求められて扔り, 各病院・施設で試行さ れている。

大腸癌は胃癌と同様に早期発見で根治が期待できる癌 である、したがって，大腸癌のルーチン検査としての役 割をも担うX線検査はまず見逃しのない検査であらねば ならない. 以下，大腸ポリープ・癌を効率良く発見する ために必要な，二重造影法を主体としたX線像の成り立 ちを放射線・投影学的観点から述べる。

\section{I . $\mathbf{X}$ 線学的基本事項}

一般にX線像の形成に与かるX線学的な現象としては 像の拡大, 歪形, 接線効果と重積効果が挙げられる.さ らにバリウムなどの造影検査では造影剤貯留現象も加わ ることになる.

像の拡大はX $\mathrm{X}$ 線束が平行ビームではなく扇状であるた め生じる現象であり, 被写体がフィルム面と離れるに従 ってその効果が強く現れる. 病変の大きさの測定に際し ては留意する必要があるが，臨床的に問題となることは 少ない. 像の歪形は被写体の厚みとX線入射方向により 生じるが, 臨床的には多方向撮影を行うことにより補正 される。

接線効果はX線が被写体のある部分に対して接線とな るとその輪郭が鮮明に投影される現象を言うが，高いX
線隇弱係数を有するバりウム造影像ではその影響は少な W.

重積効果とは，一般的にはX線束の透過した個々の臓 器のX線減弱の総和がフィルム上の濃度となることであ るが, 二重造影像ではバリウムの付着面の前後の重なり や被写体の球面（あるいは円柱面）性により生ずる現象 が主体をなす．大腸二重造影像上，腸係蹄や大腸膨隆 haustra の重なりによりバリウム濃度の高い領域や，腸 管や病変のバリウム濃度の不均一が生じる（Fig. 1).
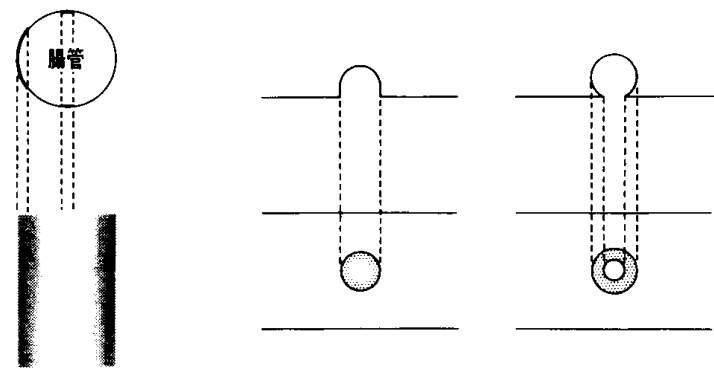

Fig.1 腸管・ポリープの二重造影像でみられる重 積効果. 均一にバリウムが付着した円柱体 (左図の腸管) や球体 (右図のポリープ)で は単位面積当りのバリウム濃度は辺縁部で は高く,中心部では低くなる(中心性消腿)。

造影剤の貯留は造影検査中でも二重造影法を行うバリ ウム造影検查に特有の現象である。一枚のフィルム上の 腸管を全て二重造影像とすることは不可能であり，程度 の差はあれ必ずみられる現象である，病変の部位とバリ ウム貯留の量および部位との関係から種々の像が出現す る（Fig. 2)．基本的にはできるだけ広い範囲の二重造影 像を撮影するようにしなければならないが，逆にこの現 象のため病変の発見や性状分析が容易となることも稀な らず経験する。バリウム貯留像の内，特異な像としてポ 


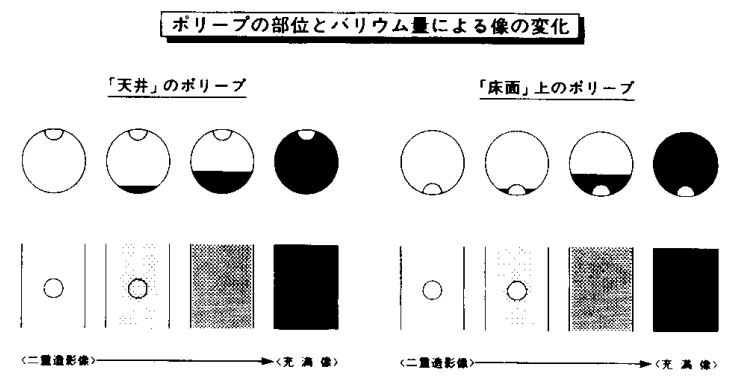

Fig. 2 ポリープの局在とバリウム貯留の局在およ び量により二重造影像から充満像に至る 種々の像がみられる。

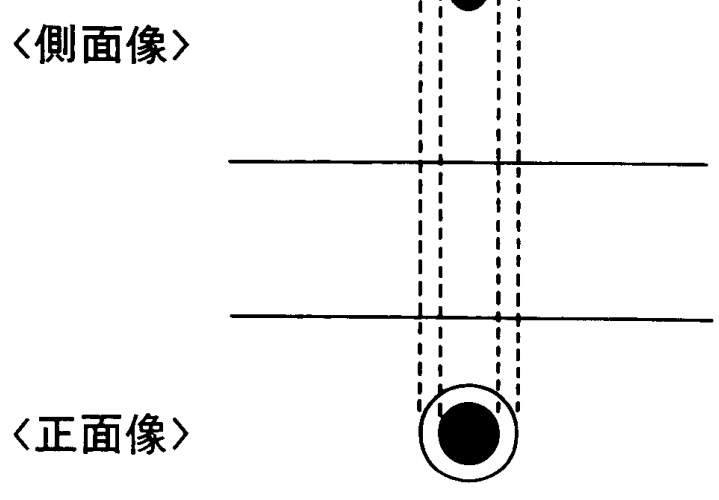

Fig. 3 滴下現象（stalactite phenomenon）.

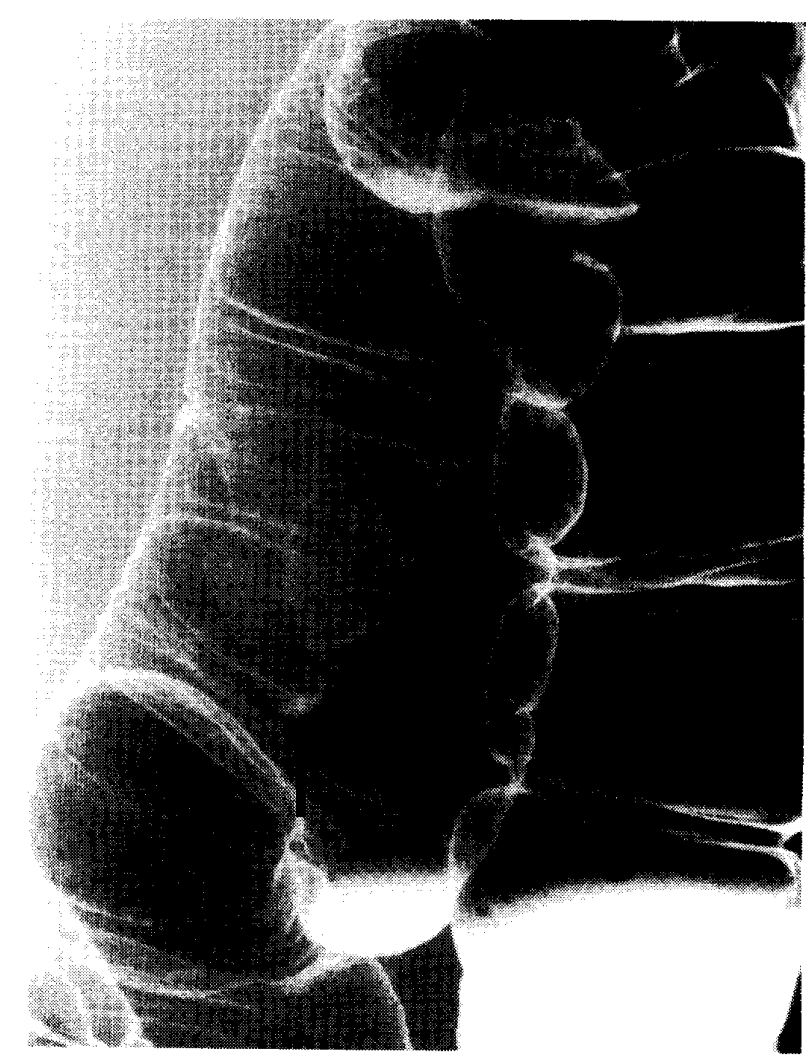

Fig. 4 横行結腸の双峰状の有茥性ポリープ. 矢印 の頭頂部に滴下するバリウムをみる。
リープが下垂したときみられる滴下現象（Fig. 3，4）が あるが，それと体位との関係から病変の局在を診断でき る.

\section{II . ポリープ・癌のX線像}

ポリープや早期大腸癌の X 線像の形成に関与する基本 的要因としては病変の病型，大きさ，投影方向抢よび陷 凹の有無が挙げられる。

大腸隆起病変はその立ち上がりの形状から，無茎性の 広基性, 菱を持った有萃性とくびれを有する中間型に分 類できる(Fig. 5).
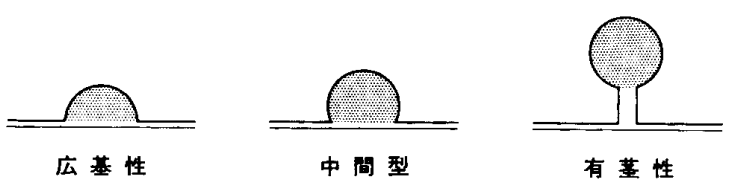

Fig.5 ポリープ・癌の基本病型.

投影方向は病変の中心軸方向に照射される正面像, 直 角方向に照射される側面像とそれらの間に種々の角度の 斜入射像がある. 各投影像は一般には患者体位を変える ことによりえられるが，多方向透視撮影装置ではX線焦 点…フィルム系の回転によりえられる。

\section{1. 広基性病変の $\mathrm{X}$ 線像}

正面像から側面像に至る各段階での病変の現れちをシ エーマとして示したのがFig.6である。正面像でみられ る病変の輪郭を示す輪状影は一般的には鮮明な像として みられその発見は容易である (Fig. 7a)。投影角度が浅く なるに従って腸管中心に向かうバリウム濃度の高い部分 が出現し hat signないしはbowler-hat signと呼ばれる (Fig. 8).さらに投影角度が浅くなると辺緣に basal indentation (BI) と言われる欠損像がみられるようにな り, BI は側面像で最も深くなる（Fig. 7b).

\section{2. 有茎性病変の X線像}

有茎性病変では他の病型と異なり荠が像の形成に加わ
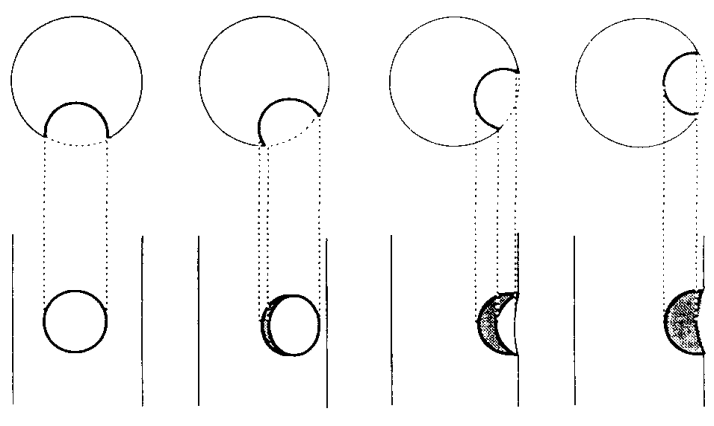

en face

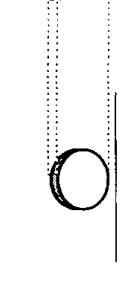

three-quarter

three quarter

Fig. 6 広基性病変の投影像. 


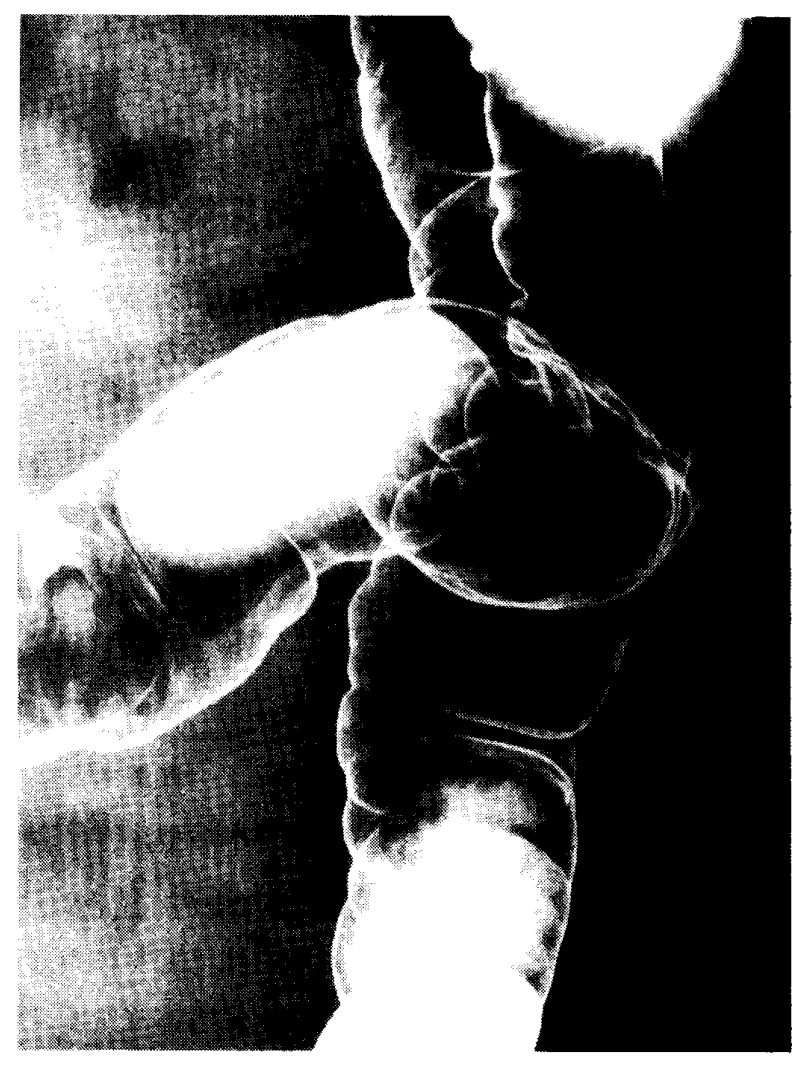

(a)

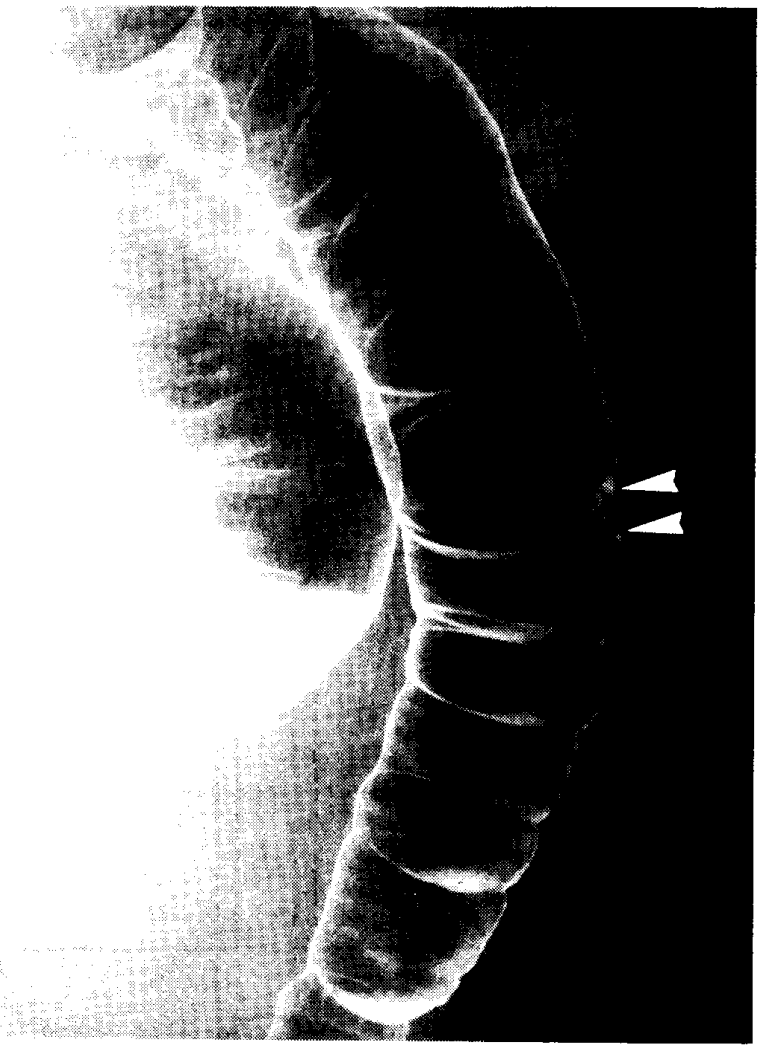

(b)

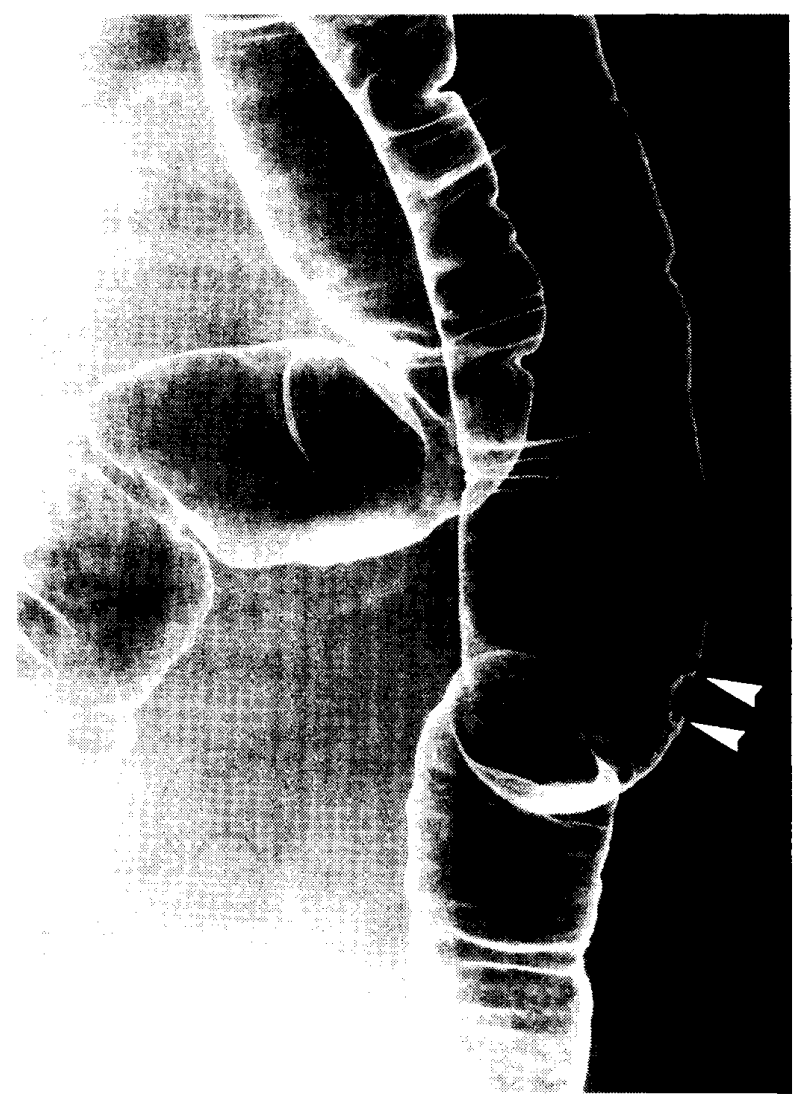

(c)

Fig. 7 下行結腸の広基性ポリープ. 正面像(a)ではハート型の境界鮮明な陰影としてみら れ，側面像(b)では半球状の腫熘影の基部に弧状の欠損像（BI）をみる。撮影体位 を変えることにより，角状 BI となる(c). 


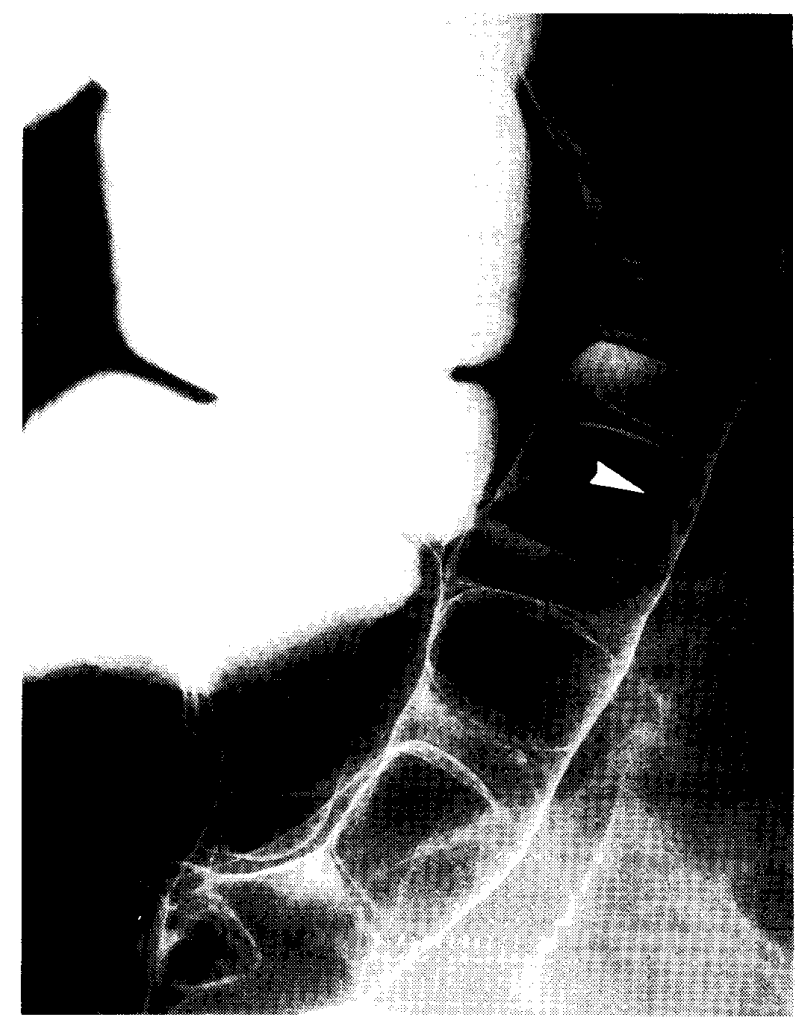

Fig. 8 下行結腸遠位部の広基性ポリープの斜入射 像でみられる hat sign。

るため，茥と㢦部扔よび脂管等との接合部の陰影が重な つた複雑な像を是する。茥は種々の長さや径のものがみ ら扎伸維性は一般に良い。有萃性病変の正面像は下乗し たときにみられ，バりウム濃度の高い頭部㓌影の中に䒝

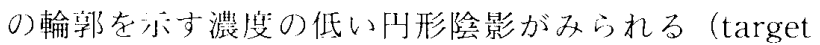
sign）(Fig.9)。側面像も孷密には下垂したときにみられ る像であるが，バリッムの流れる而にあると副部の重み で倒机斜入射像に近い像としてみら机ることが多い。そ

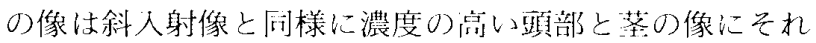
らの接命部を六寸輪状影が重なり（Fig. 10）, 基部が辺縁 にあるとBI が認められる。

\section{3. 中間型病変の $\mathrm{X}$ 線像}

中間型病変も有荠性病変と|问様に基部の輪部を示古輪 状影がみられることが特徵的である。泟面像では有茥性 と闹様に target sign がみられ，側面像では広基性と同様 にその基部に BIがみられる。X線の入射角が傾くと，2 侗の輪状影の博心がずれ (off-center sign), さらに傾く と hat sign が出現する。

\section{4. basal indentation について}

备病型の側面像に其通してみられる BI は当初より病

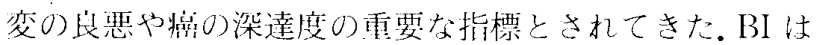
その形状から弧状，角状㧍上び台形状の3一の型に分颣 され(Fig. 11)，後考になるほど瑟性の问能性や深達度が

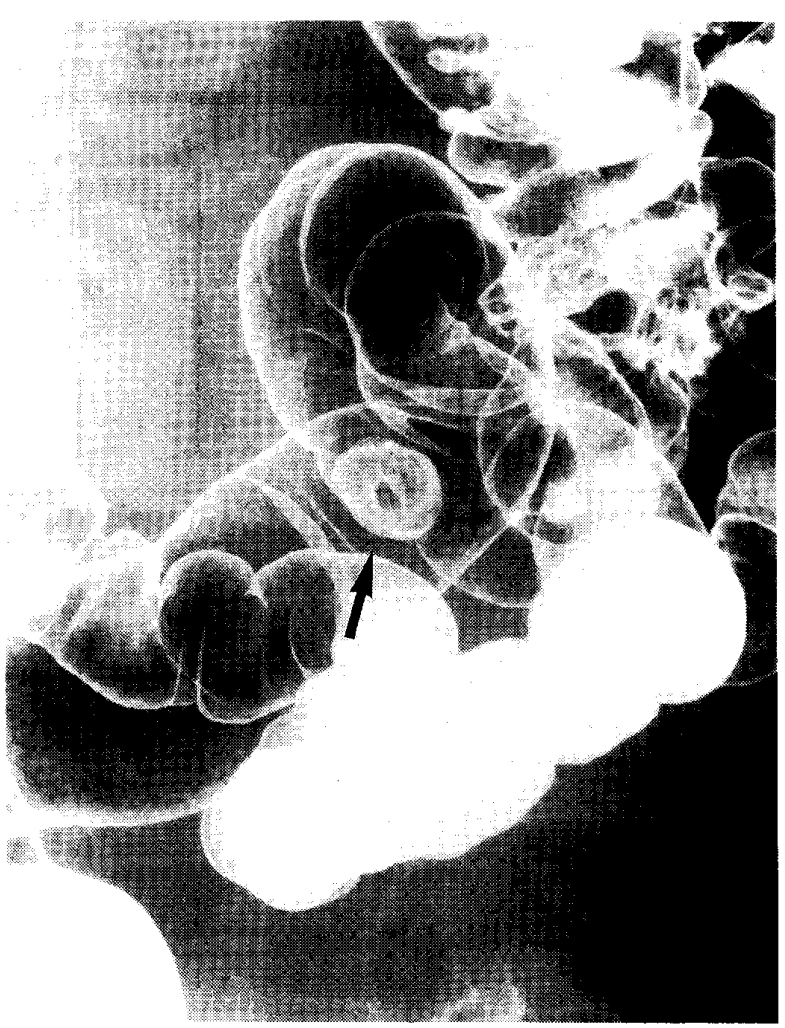

Fig.9S状結腸の有芠性ポリープでみられる target-sign.

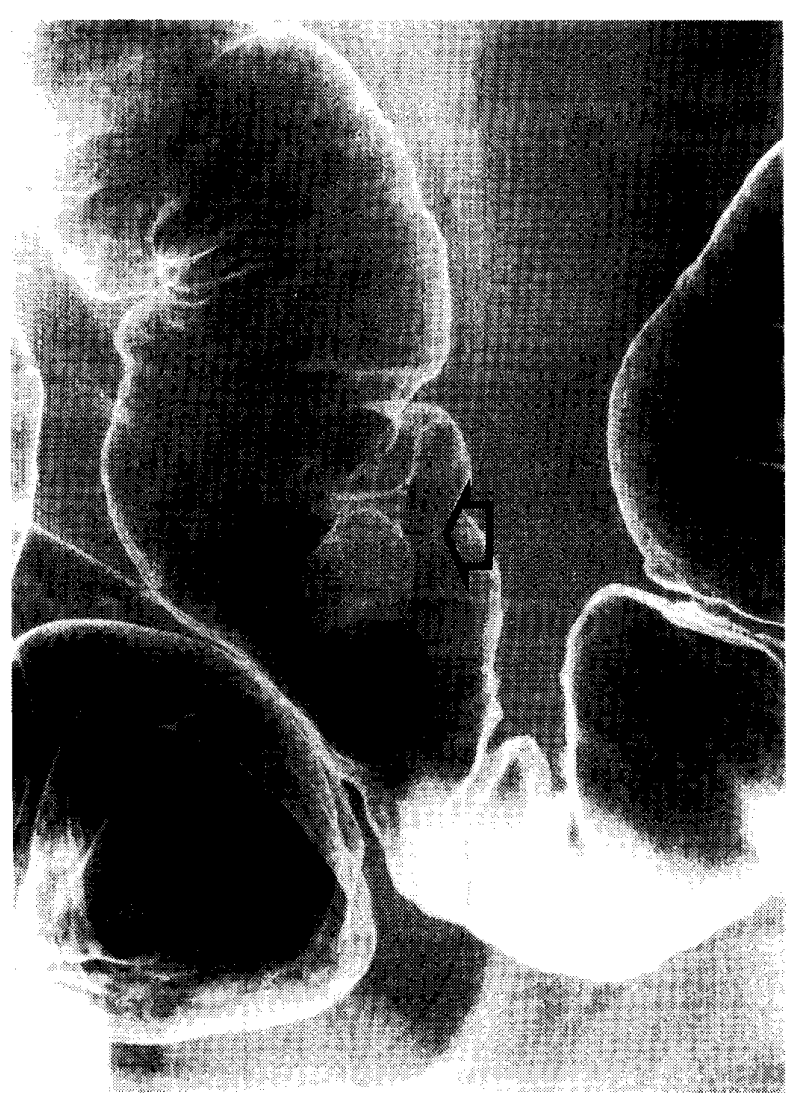

Fig. 10 S状結腸の有荎性ポリープの斜入射像. ポ リーブ頭部と兴の比較的バリウム濃度の高

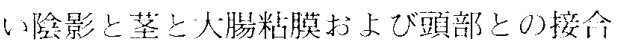
部の輪部が認められる。 


\section{Double-contrast images of BI}

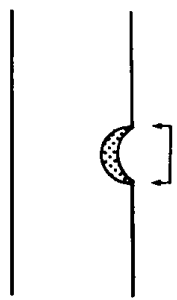

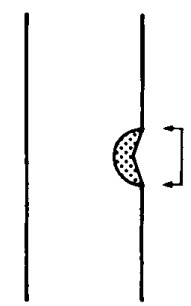

angular

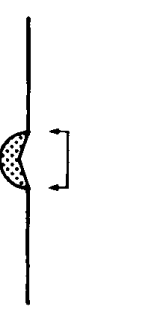

arcuate

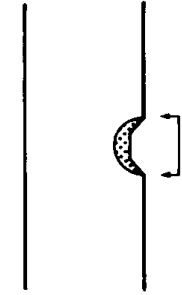

trapezoid

Fig. 11 BI の基本型.

深くなると考えられてきた。

しかし, phantom や切除標本の検討から，BI は病変と 玥常粘膜の境界点が描く 3 次元像の平面への投影による 像であることが解る，その基本となる狐状久損像は腸管 軸を中心とした 2 本の円弧の重なった像であり（Fig. 12),X線束が 90 度から腸管軸方向に傾くと 2 本の円弧が ずれ(Fig. 13)，2 本の円弧の交点を頂点とする角状変形 (“8-figure”とも言われる) が生じる（Fig. 7c).そし て, クレータを有する腫瘤でみられる台形状欠損像は, 弧状ないしは角状欠損像にクレー夕の側面像が重なって できる像である。

\section{ArGuate B]}

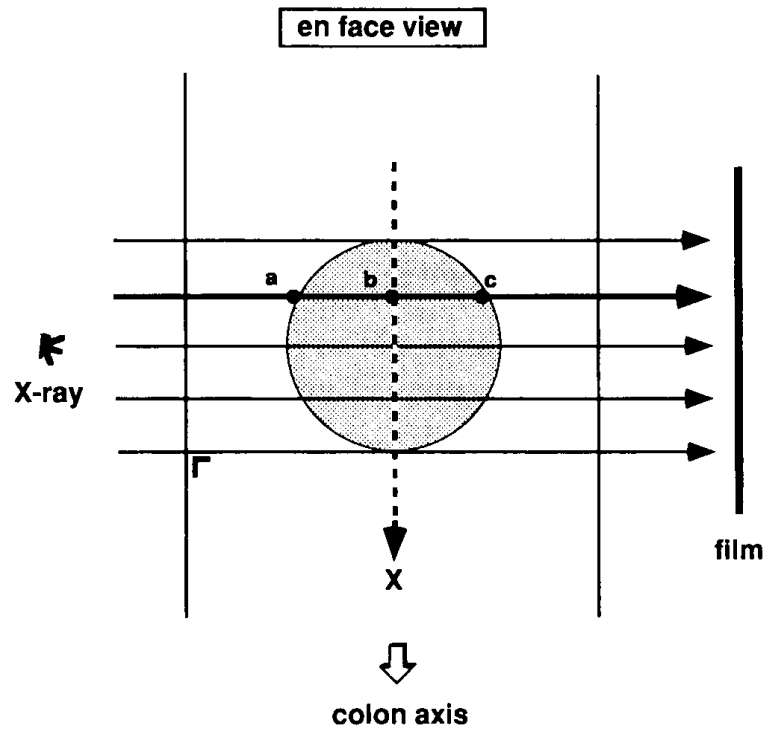

cross-section view

profile view

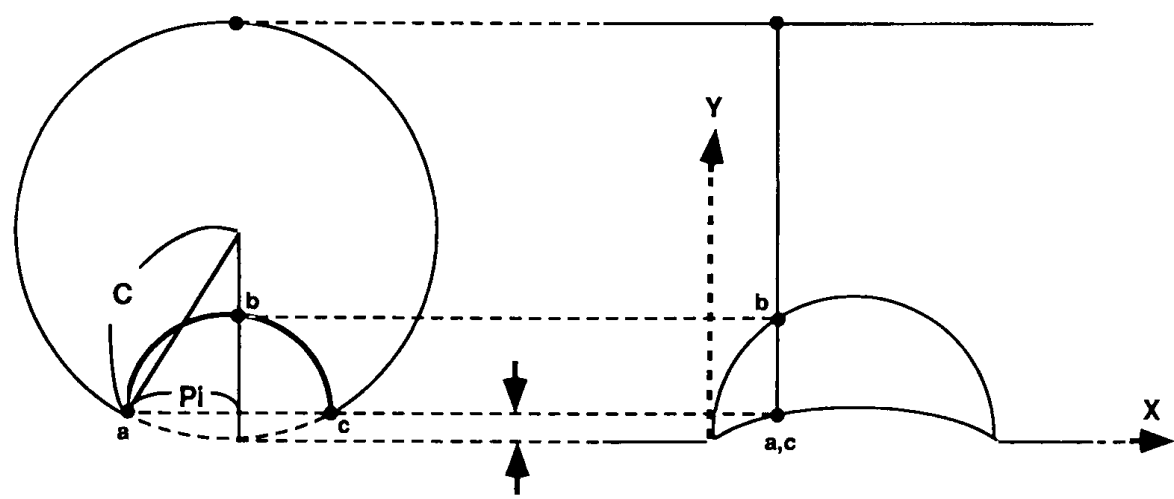

回

Fig. 12 弧状 BI の形成機序. 


\section{Angula: Bu}

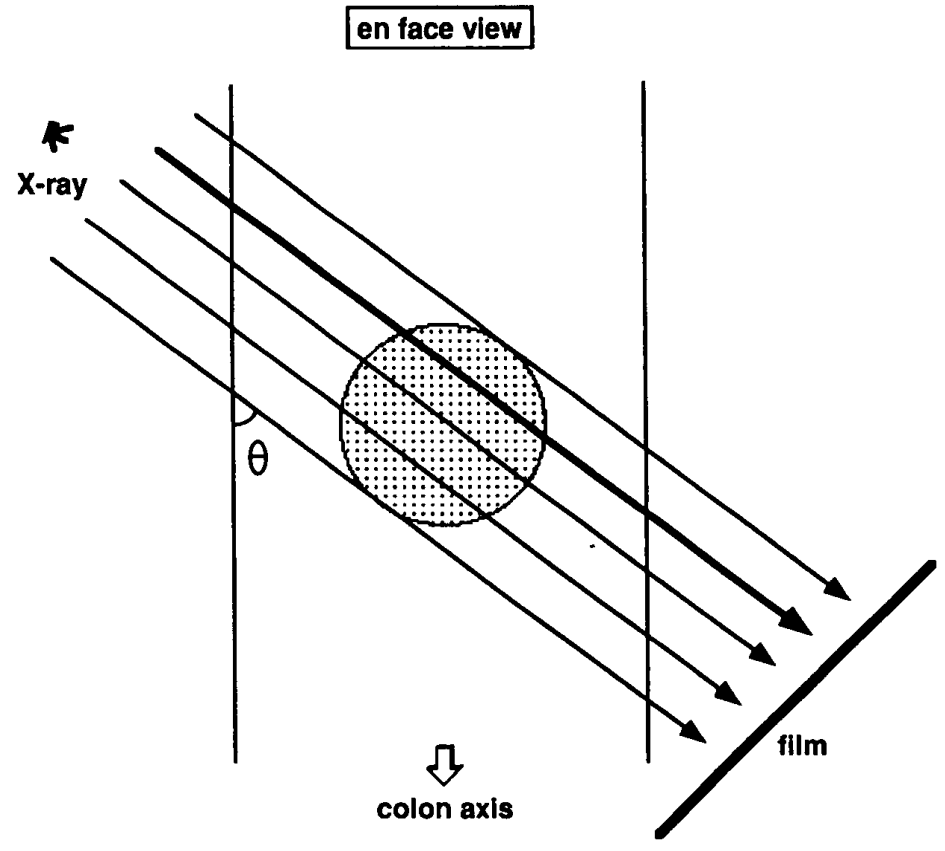

\begin{tabular}{|ll}
\hline cross-section view & profile view \\
\hline
\end{tabular}

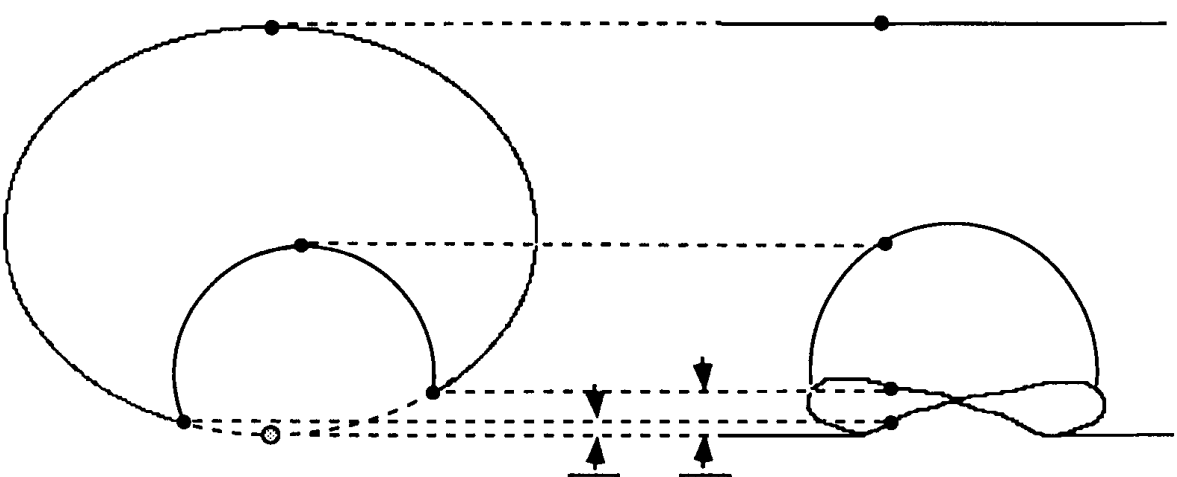

BI $\mathrm{BI}$

Fig. 13 角状 BI の形成機序.

$\mathrm{BI}$ の形状や程度 (大きさ, 深さ) は病変の大きさ, 形 状や陥凹の有無により決り，その限りでは診断学的な意 義を有するが，それらは正面像や斜入射像で容易に得ら れる所見である。また, 透視下で病変を発見したり, 予 め病変の存在部位を知っていても解剖学的な制約のため 臨床的に側面像が得られる機会は多くない.さらに, 病 変が大きくなると陽管軸中心に左右非対称となることが 多く理論的にも側面像撮影は不可能となる。

\section{III. 考察}

日本人の食生活や生活様式の欧米化に伴って大腸癌の 頻度は上昇しており，大腸検査の需要も増加している。 それに伴い, ポリペクトミという確定診断・治療手段を 有する大腸内視鏡検査は機器の改良と手技の向上からよ り危険性の少ない検査となり, 日常臨床の場で手軽に行 われるようになってきた。 
かかる現状の中でX線診断に求められる第 1 の役割は 見逃しの少ない精度の高いルーチン検査である.そのた めには残渣の少ない前処置法を採用し, 効率良く大腸全 域の二重造影像を撮影する検査手順を確立しなければな らない.

大腸癌は胃癌と比べその形状は比較的単純であり良好 な二重造影像をえれば発見は容易である。しかし，前処 置は必ずしも全ての例で完全とはいかず，また胃に比べ はるかに広い粘膜全域の二重造影像を限られた時間とフ イルム枚数でえることは不可能に近いと言える、したが つて読影に際しては前述した多彩なX線像を念頭におい て所見の有無をチェックすることと，透視時にはバリウ ムの先進部分の流れ方に留意する，特に，後者により病 変の好発する左半結腸の $1 \mathrm{~cm}$ 以上の病変の大部份が発 見できる。

病変を発見すると次に求められることはその性状診断 である、ルーチン検査で得られた限られた情報からその 肉眼形態を構築し良悪性や深達度診断をするが, その正 診率は満足できるものではなく肉眼形態診断の限界でも あり，最終的にはポリペクトミなどの全標本の組織診断 に委ねることになる。したがって，X線診断のもう1つ の役割は, 病変の大きさ, 病型, 茎や陷凹の有無から内 視鏡的切除が可能か否かを判断しなければならない。

\section{【文献】}

1）立入 弘監修, 山下一也, 速水昭宗編集診療放射線 技術上巻，南江堂，1985
2) Youker JE et al: Differentiation of true polypoid tumors of the colon from extraneous material: A new roentgen $\sin$.

3) Weissman A et al : Double contrast examination of the colon; Principles and practice. SpringerVerlag, Berlin, 1979.

4）丸山雅一：X線診断一ポリープ・癌の存在診断と質 的診断一。臨放25:709-716, 1980 .

5) Ament $\mathrm{AE}$ et al: Basal indentation of sessile polypoid lesions; a function of geometry rather than a sign of malignancy. Radiology 143: 341344, 1982.

6) Ott DJ et al: Colon polyp morphology on double-contrast barium enema: Its pathologic predictive value. AJR 141 : 965-970, 1983.

7) Olmsted WW et al: The solitary colonic polyp : Radiologic-histologic differentiation and significance. Radiology 160: 9-16, 1986.

8）牛尾恭輔ほか：消化管のX線診断における側面像の 意義一二重造影像による深達度診断一, 胃と腸 21 ： 27-41, 1986.

9）佐藤正之ほか：ルーチン性腸造影法のポリープ検出 能. 臨放31：1109-1113，1986.

10）佐藤正之ほか：Basal indentation(BI) のX線・幾 何学的検討一phantom および大腸切除標本を用い て一。臨放34：1555-1561，1989。 